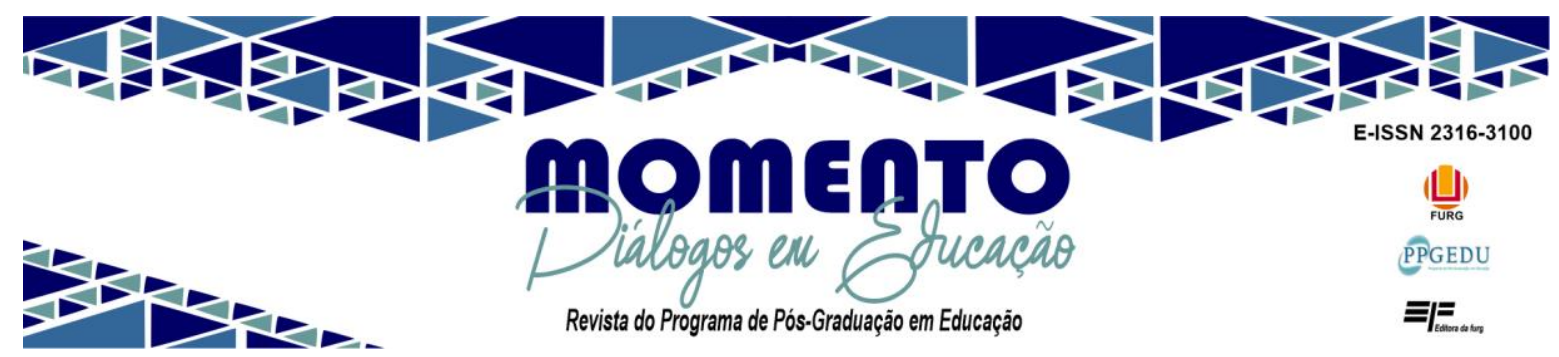

\title{
A RELAÇÃO ENTRE FAMÍLIA E ESCOLA NA COMUNIDADE DO POVO NOVO PELA PERSPECTIVA DO DESENVOLVIMENTO BIOECOLÓGICO
}

\author{
Hardalla Santos do Valle ${ }^{1}$ \\ Adriana Coronel ${ }^{2}$
}

\begin{abstract}
Resumo: o presente trabalho tem como objetivo discutir a relação entre família e escola na comunidade do $3^{\circ}$ Distrito do Povo Novo (Rio Grande/RS), uma zona rural que possui em torno de 8 mil habitantes e constitui a sua base econômica a partir de atividades relacionadas à pecuária, à agricultura e aos pequenos comércios. Para compreender a relação entre família e escola, foram realizadas entrevistas semiestruturadas com educadores e familiares de crianças do $3^{\circ}$ ano do Ensino Fundamental, pertencentes a 3 escolas públicas da localidade. $\mathrm{O}$ aporte teórico utilizado foi a bioecologia do desenvolvimento humano, elaborada por Bronfenbrenner (2011), a qual postula que, durante o processo de desenvolvimento humano, diferentes circunstâncias sociais podem afetar as características subjetivas de um indivíduo. Conclui-se, neste artigo, que a teoria bioecológica pode contribuir para a compreensão da relação entre família e escola, agregando também ao processo de ensino e aprendizagem das crianças.
\end{abstract}

Palavras-chave: Família. Escola. Teoria Bioecológica. Desenvolvimento Humano.

\section{LA RELACIÓN ENTRE FAMILIA Y ESCUELA EN LA COMUNIDAD DEL PUEBLO NUEVO DESDE LA PERSPECTIVA DEL DESARROLLO BIOECOLÓGICO}

Resumen: El presente trabajo tiene como objetivo discutir la relación entre familia y escuela en la comunidad del $3^{\circ}$ Distrito del Pueblo Nuevo (Río Grande/RS), una zona rural que posee alrededor de ocho mil habitantes y constituye su base económica a partir de actividades relacionadas a la ganadería, agricultura y los pequenos comercios. Para comprender la relación entre familia y escuela, se realizaron entrevistas semiestructuradas con educadores y familiares de niños del $3^{\circ}$ año de la Enseñanza Fundamental, pertenecientes a 3 escuelas públicas de la localidad. El aporte teórico utilizado fue la bioecología del desarrollo humano, elaborada por Bronfenbrenner (2011), la cual postula que, durante el proceso de desarrollo humano, diferentes circunstancias sociales pueden afectar las características subjetivas de un individuo. Por lo tanto se concluye, en este artículo, que la teoría bioecológica puede contribuir para la comprensión de la relación entre familia y escuela, agregando también al proceso de enseñanza y aprendizaje de los niños.

Palabras clave: Familia. Escuela. Teoría Bioecológica. Desarrollo Humano.

\section{THE RELATIONSHIP BETWEEN FAMILY AND SCHOOL IN THE PEOPLE NOVO COMMUNITY FROM THE PERSPECTIVE OF BIOECOLOGICAL DEVELOPMENT}

Abstract: This work aims to discuss the relationship between family and school in the community of 3rd district of Porto Novo (Rio Grande/RS), a rural area that has around eight thousands

\footnotetext{
${ }^{1}$ Doutora em Educação (PPGE-UFPEL). Mestra em Educação (PPGE-UFPEL). Graduada em Pedagogia e História (FURG). Professora do Município de Rio Grande (PMRG).

${ }^{2}$ Graduada em Pedagogia-FURG.
} 


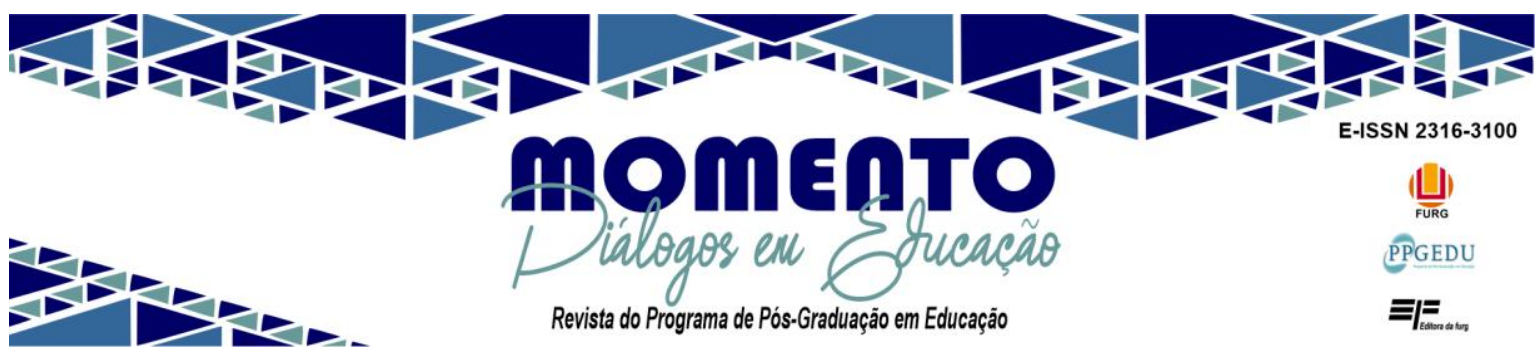

inhabitants and constitutes its basis economic activities from related activities to livestock farming to agriculture and small businesses. To understand the relationship between family and school were hold interviews with educators and family of children on the third year of elementary School, belonging to 3 public school in the locality. Theorical contribution used was the bioecology of human development by Bronfenbrenner (2011) who postulate that during the process of human development different social circumstances may affect the subjective characteristics of an individual. It is concluded in this article that bioecological theory can contribute to understanding the relationship between families and school by adding to the process of teaching and learning children

Keywords: Family. School. Theory Bioecological. Human Development.

\section{Introdução}

A relação entre família e escola é um tema que vem sendo discutido no meio educacional. Carvalho (2000) afirma que essas duas esferas estabelecem uma relação que além de se basear em supostos ideais comuns, têm a responsabilidade da divisão do trabalho de educar crianças e jovens, envolvendo-se em expectativas recíprocas. Nessa lógica, para Dessem e Polonia (2005), a escola e a família são duas instituições essenciais na construção dos processos de desenvolvimento dos indivíduos, sendo elas responsáveis pela construção do conhecimento culturalmente organizado.

Entretanto, mesmo com os debates, pesquisas e documentos oficiais, como a Constituição Federal (BRASIL, 1988), a Lei de Diretrizes e Bases da Educação Nacional (BRASIL, 1996) e o Estatuto da Criança e do Adolescente/ECA (BRASIL, 1990), que defendem a sua importância, a relação entre família e escola ainda representa um desafio para o sistema educativo, panorama que justifica a necessidade de continuar tal discussão, tecendo novos olhares para ambos os microssistemas.

Assim sendo, o objetivo desta pesquisa foi compreender a relação entre família e escola na comunidade do $3^{\circ}$ distrito do Povo Novo (Rio Grande/RS), uma zona rural, com uma média de oito mil habitantes e com a sua base econômica pautada na pecuária, agricultura e pequenos comércios. A lente escolhida para este estudo foi a teoria bioecológica de Bronfenbrenner (2011), que aborda o desenvolvimento humano como um fruto da interação entre o organismo humano e seu meio ambiente.

Para compreender essa relação, foram entrevistados educadores e familiares de crianças do $3^{\circ}$ ano do ensino fundamental de 3 escolas da localidade. A fim de proteger as 


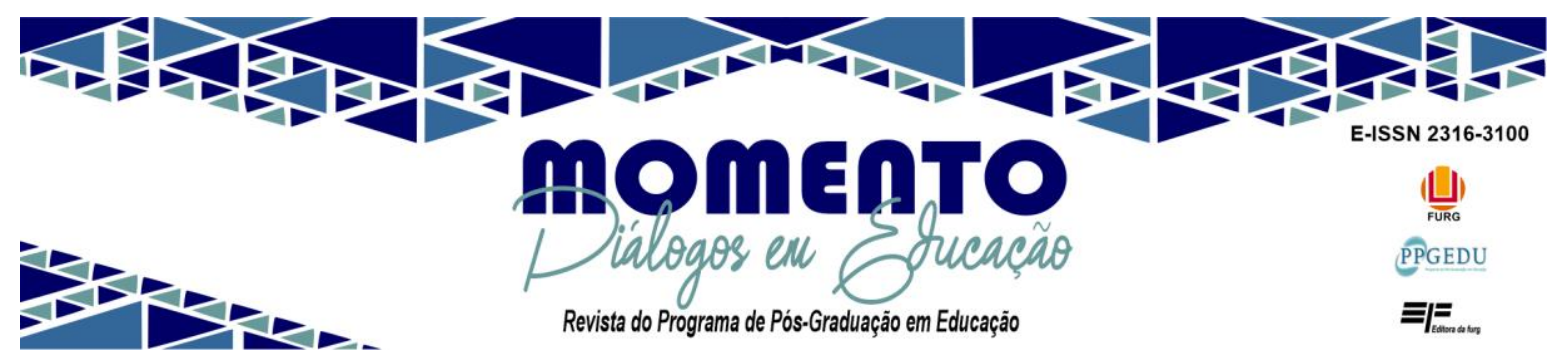

suas identidades e preservar os aspectos éticos da pesquisa, as escolas serão denominadas como Amarela, Branca e Cinza, assim como os nomes dos participantes, que serão fictícios.

As questões centrais desta pesquisa são: Como funciona a relação entre família e escola na comunidade do Povo Novo? De que forma a teoria bioecológica pode contribuir para essa relação?

A seguir, este artigo está organizado em três seções. A primeira refere-se aos elementos teórico-metodológicos da pesquisa. A segunda aborda a relação entre família e escola e a última seção apresenta a análise dos dados.

\section{Os bastidores da pesquisa}

O primeiro passo deste estudo foi a pesquisa bibliográfica, de cunho qualitativo. Conforme esclarece Pizzani (2012), essa tipologia de pesquisa busca compreender algo por meio de referenciais teóricos publicados na literatura científica. Logo após, foram organizadas e realizadas as entrevistas semiestruturadas, para a posterior análise dos dados. Cabe destacar que, como técnica de análise de dados, optou-se por entrevistas reflexivas, que são explicadas por Szymanski (2000) como uma interação social que se constitui partindo da influência mútua do entrevistador e do entrevistado em um espaço relacional de conversa interpelado por um linguajar que ajusta ações e emoções.

A forma como deve ser desenvolvida uma pesquisa, segundo a proposta de entrevista reflexiva, é organizada nas seguintes etapas: (a) o contato inicial; (b) a condução da entrevista, que é subdividida em aquecimento, a questão desencadeadora, a expressão da compreensão, a produção de sínteses e a elaboração de questões focalizadoras, de esclarecimento e de aprofundamento e (c) devolução. Outro fator a ser considerado é o de que o entrevistador e o conteúdo de sua investigação estão completamente ligados, impossibilitando uma suposta neutralidade. A compreensão de que o autor faz parte do processo é muito importante, porém não se pode deixar que isso influencie na subjetividade da pesquisa. Dessa forma, o entrevistador não pode se levar pelas distrações que ocorrem com entrevistas realizadas em contextos sociais ou perder elementos importantes que permeiam esse ambiente, assim como não pode ignorar a prática do registro contínuo, não somente das falas, mas também de outros elementos, como suas impressões e percepções. 


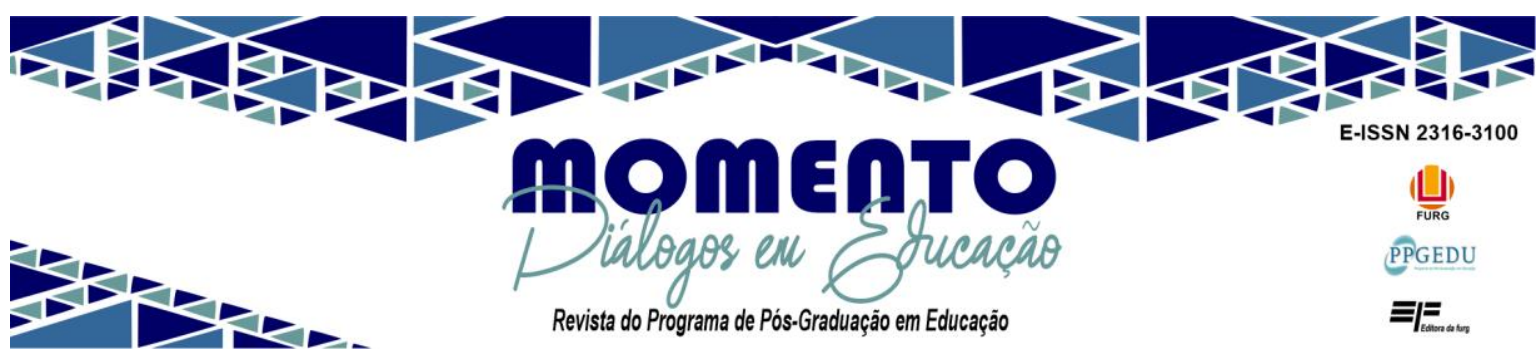

Nesta pesquisa, as entrevistas foram efetivadas nas escolas Amarela, Branca e Cinza, entre os meses de abril e de outubro de 2019, em horários diversos e condizentes com as rotinas dos entrevistados. Cumpre informar que essas escolas de educação básica se diferenciam entre as unidades federativas, sendo uma estadual de ensino fundamental e médio e duas municipais, as quais atendem educação infantil e anos iniciais. A escolha de turmas do $3^{\circ}$ ano do ensino fundamental relaciona-se ao encerramento do ciclo de alfabetização, marco de uma etapa de ensino.

Foram entrevistados 9 familiares ou responsáveis, 3 coordenadoras pedagógicas (uma de cada escola) e 3 professoras (uma de cada turma e escola). Nas escolas Amarela, Branca e Cinza, as entrevistas com as coordenadoras pedagógicas e professoras pautaramse em aspectos que buscaram entender de que forma acontece a participação dos responsáveis pelas crianças (familiares) durante a construção da sua aprendizagem e a reformulação dos documentos escolares, como o Projeto Político Pedagógico (PPP). Assim, buscou-se perceber como essas organizações pedagógicas enxergam as configurações familiares nos tempos atuais e como percebem o interesse das famílias diante das aprendizagens no cotidiano das instituições, investigando, também, as possíveis sugestões que as coordenadoras teriam para que a relação da escola com a família pudesse ser construtiva.

Em relação aos familiares dos alunos, buscou-se compreender o vínculo afetivo dos entrevistados com suas respectivas crianças, o que as mães/pais e responsáveis, participantes da pesquisa, pensam a respeito de suas participações nas atividades propostas pela escola, bem como se dedicam algum tempo para apoiar suas crianças diante das atividades propostas. Além disso, buscou-se observar se os familiares consideram relevante ou não as influências que os indivíduos que compõem a comunidade escolar podem exercer sobre as crianças, assim como observar, entre esses, se existem sugestões para que a relação famíliaescola seja positiva para todos os envolvidos nesse processo.

No que tange à Teoria Bioecológica, alicerce desta pesquisa, pode-se afirmar que ela proporciona uma visão mais sistêmica, mostrando que vários contextos se integram ao humano, de forma não fragmentada, estabelecendo uma inter-relação. Seu autor, Urie Bronfenbrenner, foi um psicólogo de origem russa, radicado nos Estados Unidos, que viveu 


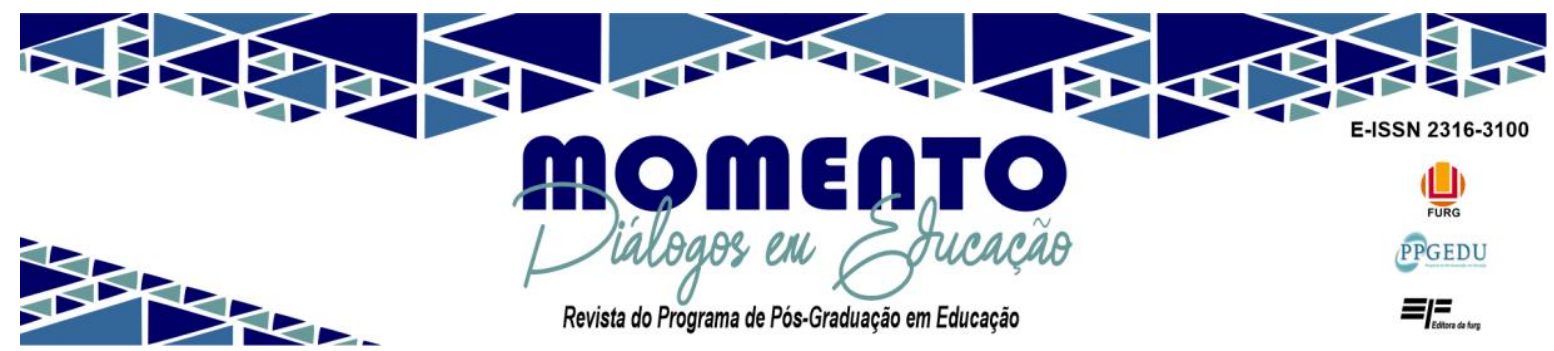

oitenta e oito anos. Conforme Martins e Szymanski (2004), ele foi primeiramente conhecido por sua teoria de sistemas ecológicos, aos quais dando continuidade a essa abordagem, mais tarde, passou a configurá-la em um modelo bioecológico, através da inclusão de novas formas de olhar para a pessoa em desenvolvimento.

Bronfenbrenner (1996) conceituou o desenvolvimento humano como um produto da interação entre o organismo humano em crescimento e seu meio ambiente. Dessa forma, embora essa afirmação pareça algo simples, carrega a complexidade que envolve o humano no seu constante desenvolvimento.

Dando continuidade a esse raciocínio, Bronfenbrenner (2011) afirmou que, durante o processo de desenvolvimento humano, qualquer movimento dentro da sociedade pode afetar as características subjetivas de um indivíduo, definidas pelo teórico como aspectos multidirecionais inter-relacionados, o que é designado como modelo PPCT: "pessoa, processo, contexto e tempo". Esses quatro aspectos estão definidos por Bronfenbrenner (2011) como multidirecionais inter-relacionados, os quais, partindo das premissas do autor, são definidos a seguir.

Pessoa: refere-se à importância de considerar as características identitárias do indivíduo em desenvolvimento. Exemplos: gênero, cor da pele, idade, convicções, temperamento, metas, motivações.

Processos: são as interações e ações (atividades molares) nos contextos.

Contextos: referem-se ao meio ambiente global em que o indivíduo está inserido e onde se desenrolam os processos desenvolvimentais, levando em consideração os parâmetros das esferas micro, meso, exo e macrossistemas, que podem influenciar a pessoa em desenvolvimento a partir da forma como esses parâmetros irão agir sobre ela, exercendo influências e moldando o curso de seu desenvolvimento.

Tempo: é visto conforme a etimologia da palavra, através da divisão de segundos, minutos, hora, dia, mês, ano, etc., formando eventos históricos que poderão constituir e/ou alterar os indivíduos, influenciando-os e dando seguimento geracional à humanidade, estando atrelada a ritos de passagem da sociedade e a mudanças de comportamento social diante do caminhar social. Também está relacionado à percepção individual sobre as rotinas e a organização do cotidiano.

Os elementos particulares da interação do humano nas suas relações são entendidos 


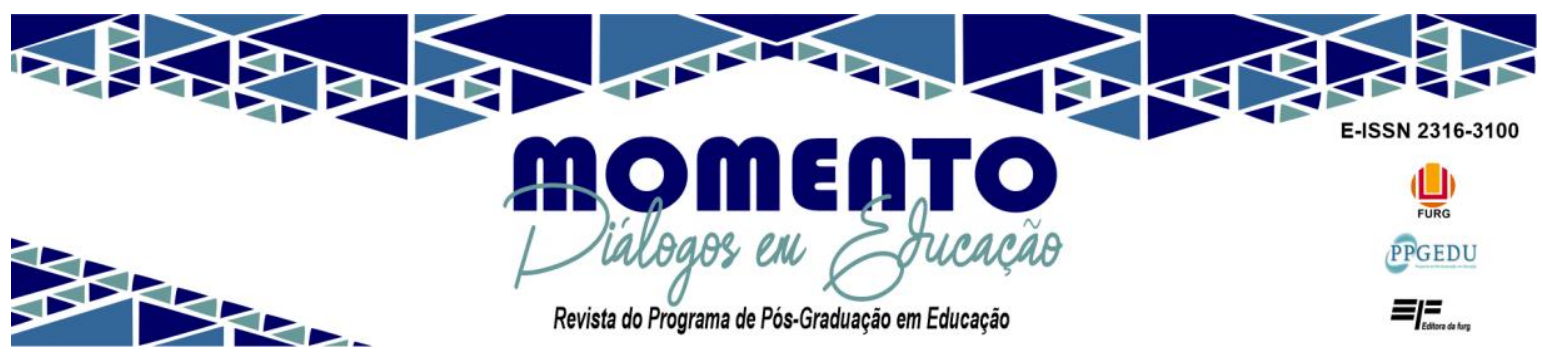

por Bronfenbrenner (2011) como "processos proximais". Conforme o autor, pode ser entendido por um processo de interação recíproco e complexo que se dá de forma progressiva "entre um organismo humano biopsicológico em atividade e as pessoas, objetos e símbolos existente no ambiente externo imediato" (BRONFENBRENNER, 2011, p. 46). Dessa forma, as relações entre pais e criança, atividades entre crianças ou em grupo rotineiros e de crianças com professores em sala de aula, principalmente nos anos iniciais da educação básica, em que a professora permanece um tempo mais constante e próxima à criança caracterizam-se como processos proximais.

Esse autor criou parâmetros que reforçam as características biopsicoambientais do humano através de suas estruturas formadas a partir de uma hierarquia em níveis, chamados pelo autor de micro-, meso-, exo-, macro-e cronossistemas.

Algo relevante, que merece destaque para essa pesquisa, são as considerações do teórico frente ao que ele aponta estar se passando no contexto familiar:

O cerne da questão é este: os pais não são eficazes porque a situação ecológica não permite que sejam. Os contextos ecológicos nos quais os pais e outras pessoas envolvidas com as crianças vivem em sociedade são de tal modo complexos que não há tempo, lugar, referência ou reforço para interações com as crianças. Vive-se em uma sociedade segregada pela idade na qual crianças e adultos levam vidas separadas. (BRONFENBRENNER, 2011, p. 76).

Em vista da globalização, os problemas trazidos pelo teórico no excerto acima, embora pertencente a outro continente, enquadram-se no contexto do Brasil. Nesse sentido, os desafios familiares que podem levar à pouca interação dos pais com as crianças podem ter origem no cansaço do trabalho frente à busca pelo sustento familiar, às múltiplas tarefas, bem como ao uso das tecnologias enquanto entretenimento. Isso mostra o quanto os indivíduos podem ser afetados pelos níveis dos parâmetros sistêmicos estudados na ciência do desenvolvimento humano, o que reforça a ideia de que o cotidiano humano, embora pareça simples, carrega consigo uma grande complexidade. A preocupação trazida no excerto por Bronfenbrenner (2011) pode ser associada à necessidade de os professores estarem atentos aos movimentos familiares, entendendo que podem influenciar no processo de aprendizagem das crianças no contexto escolar. 


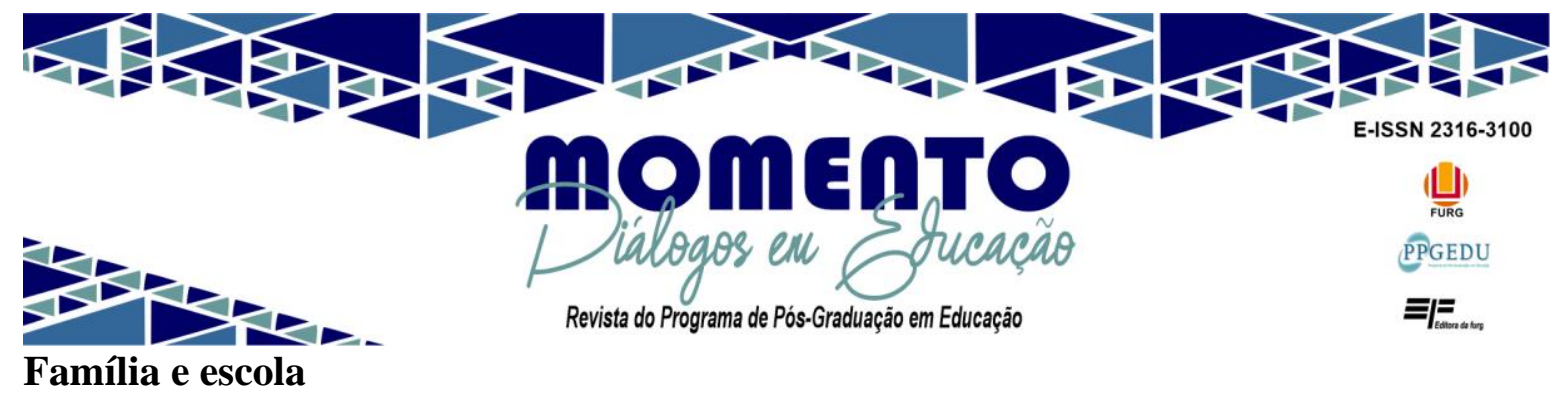

A trajetória de uma criança, desde o nascer, é constituída a partir de uma imersão nas engrenagens sociais. Nelas, a família e a escola possuem um papel fundamental, já que é dentro dessas instituições que os sujeitos constituirão seus relacionamentos, a linguagem e se encaminharão economicamente e culturalmente. Entretanto, é sabido que essas instituições não se constituem em padrões familiares ou escolares perfeitos, mas que estão emaranhadas em um mundo real, dimensionado em conflitos naturais do desenvolvimento humano. Dessa forma, para Bronfenbrenner (2011), a família configura-se dentro de uma compreensão microssistêmica que abarca as interações, os conflitos e os cuidados de forma imediata entre seus membros.

Cabe salientar que sempre existiu a diversidade na composição das famílias. Assim, vivemos em um mundo em que existem famílias compostas por pais héteros, gays, casados, divorciados, por avós cuidando dos seus netos, por irmãos e/ou tios cuidando da criança, entre uma infinidade de arranjos na sua composição e nas relações entre seus membros.

Contudo, o ato de educar continua presente entre essas famílias, mantendo-se significativamente influente à criança diante do seu futuro e se estendendo à fase adulta. Essa ação é esclarecida pela teoria bioecológica da seguinte forma: "as crianças se tornam isomórficas com seu ambiente social, em virtude da interação que ocorre entre os participantes nesse núcleo ecológico" (BRONFENBRENNER, 2011, p. 68). Nessa lógica da teoria bioecológica, as crianças vão vivenciando esses modelos sociais de maneira a naturalizá-los e subjetivá-los, de tal forma que a dinâmica familiar, dentro do quadro social, ainda mantém-se provedora não só dos cuidados com a saúde física e psíquica, valores e princípios éticos, crenças e cultura, mas também do vínculo afetivo, que pode ser relevante à construção da identidade do indivíduo, servindo de alicerce junto às conquistas de espaço na sociedade, podendo influenciar os sentimentos, as razões e as atitudes das crianças frente à vida.

Entretanto, por mais que o vínculo afetivo estreite os laços da relação familiar, não pode servir como único artifício para sustentar um desenvolvimento escolar pleno para a criança. Carvalho (2000) lembra que as condições sociais e econômicas podem influenciar nas aprendizagens escolares. Nessa lógica, pais com baixo nível de escolaridade e pouco 


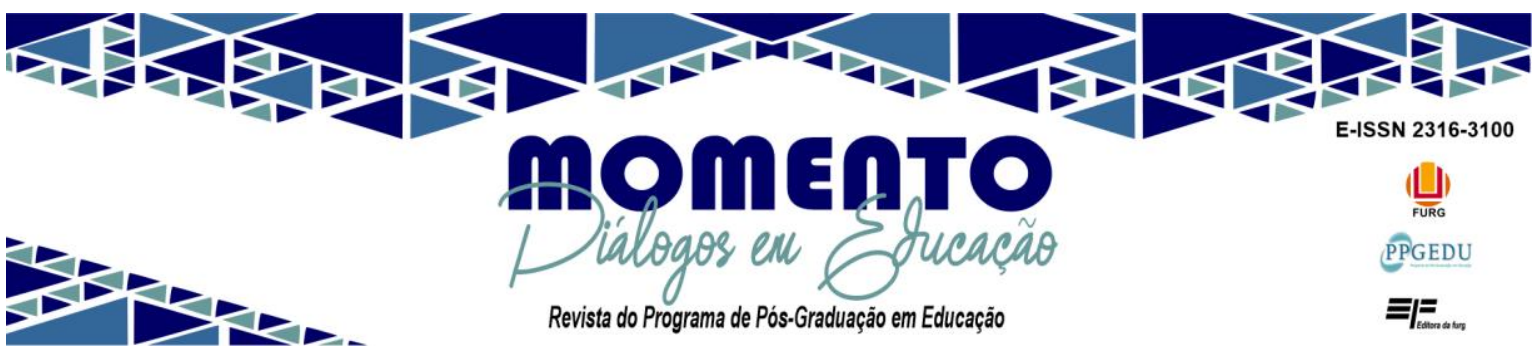

poder aquisitivo podem enfrentar algumas dificuldades frente à tarefa de apoiar suas crianças nos assuntos pertinentes à escola. Entender os desafios presentes nas realidades das famílias mostra-se, assim, fundamental à escola. Do mesmo modo, quanto mais os pais conhecerem as dificuldades da escola e estiverem dispostos a contribuir para o bom andamento do ensino, melhor será para a criança.

De acordo com o ECA (BRASIL, 1990), em seu Art. 53, as crianças e os adolescentes têm o direito à educação visando ao pleno desenvolvimento de sua pessoa e preparando-os para serem cidadãos, citando, como direito dos pais ou responsáveis, o conhecimento dos processos pedagógicos e a participação da construção das propostas educacionais da escola.

No que se refere ao amparo à criança e ao adolescente, as legislações que defendem esse direito são claras, exigindo que ambas instituições assegurem a frequência desses menores em instituições educativas formais, sob o risco de sofrerem sanções. Dessa forma, a Constituição Federal (BRASIL, 1988), no seu Art. 227, declara que é dever da família, da sociedade e do Estado assegurar às crianças, aos jovens e aos adolescentes, o direito à educação e à cultura. Ademais, encontra-se, na Lei de Diretrizes e Bases da Educação Nacional:

Art. $2^{\circ}$ : A educação, dever da família e do estado, inspirada nos princípios de liberdade e nos ideais de solidariedade humana, tem por finalidade o pleno desenvolvimento do educando, seu preparo para o exercício da cidadania e sua qualificação para o trabalho. (BRASIL, 1996).

Portanto, a legislação deixa claro que a formação das crianças não é função somente da escola ou da família, mas das duas instituições com o apoio da sociedade. Uma consciência acerca da integração positiva da família com a escola pode alavancar uma mudança nos níveis cognitivos, sociais, afetivos e de aspectos da personalidade dos estudantes de forma evolutiva, garantindo o pleno desenvolvimento de crianças e jovens. Dessa forma, dentre as diversas funções do papel social familiar, o educar e o cuidar vêm sendo compartilhados com escola, o que tem tornado a relação de ambas reflexiva para aqueles que se preocupam com a educação, com o desenvolvimento humano e para onde caminha a sociedade. 


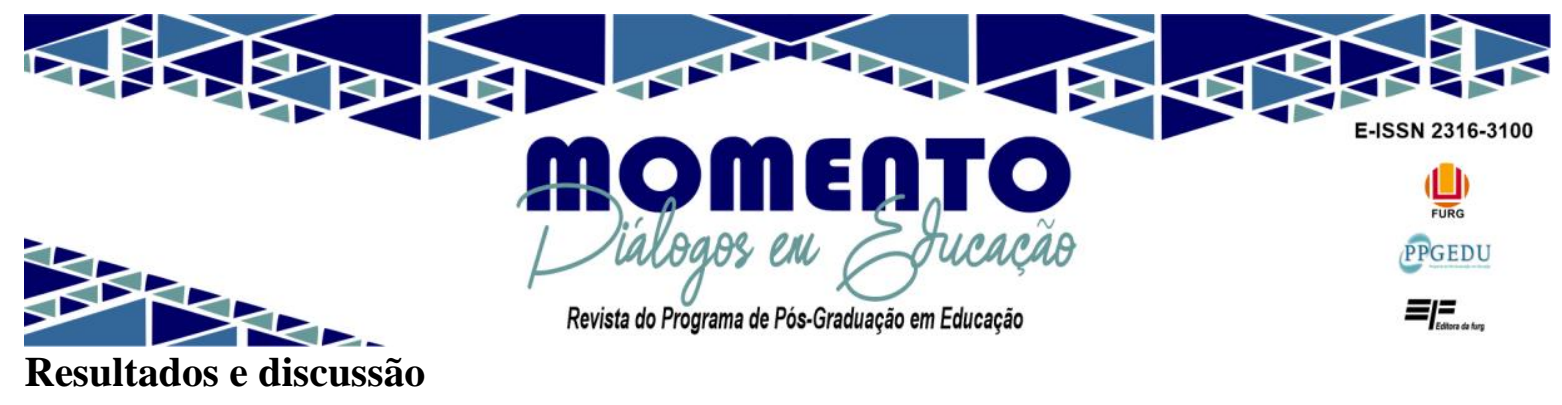

Ao se pensar em possibilidades de desenvolvimento dentro desse ecossistema, em caminhos que contribuam para uma relação construtiva entre a escola e a família, percebese a necessidade desses dois setores se autoanalisarem.

Conforme Poliana e Dessem (2007), para que se possa compreender aspectos gerais da integração família-escola, assim como as peculiaridades de cada um desses ambientes, a relação precisa ser identificada, aprendida e analisada com intuito de propiciar uma melhor compreensão de ambas e o entendimento de aspectos mais característicos de cada um desses ambientes.

Nesse sentido, passa-se a trazer, neste trabalho, aspectos relevantes acerca das entrevistas que ocorreram no Povo Novo. Peculiarmente, nessa comunidade, ainda se preserva uma relação, entre seus moradores, de muita proximidade, onde as famílias ainda se identificam a partir dos sobrenomes, configurando laços afetivos estreitos entre seus residentes. O nível de escolarização, da maioria da população, é o ensino fundamental, devido ao ensino médio ter sido ofertado à comunidade somente no ano de 2004.

Outro aspecto relevante para a pesquisa, durante o seu processo de desenvolvimento, foi a presença massiva da mulher enquanto educadora. Nos papéis de mãe, tia e professora subentendeu-se tal função.

No que se refere a aspectos da dinâmica da escola com as famílias, foi possível observar que as três escolas realizam reuniões periódicas trimestrais para o ato de entrega das avaliações, nas quais também são tratados assuntos atinentes aos eventos do calendário escolar, bem como todo tipo de demanda que possa surgir no que tange à criança, dentro do contexto escolar ou fora dele.

Por meio das entrevistas, as coordenadoras pedagógicas das escolas Amarela e Cinza demonstraram que seu trabalho se dá, geralmente, de forma indireta, operando com as famílias através das professoras. Nesse sentido, essas duas escolas demonstraram que, na construção do PPP, há participação das famílias, por meio de questionários ou entrevistas, sobre os aspectos principais que compõem o documento.

Em relação à percepção das coordenadoras frente aos variados modelos familiares existentes nas escolas Amarela e Cinza, as duas trouxeram o alerta de que as famílias vêm 


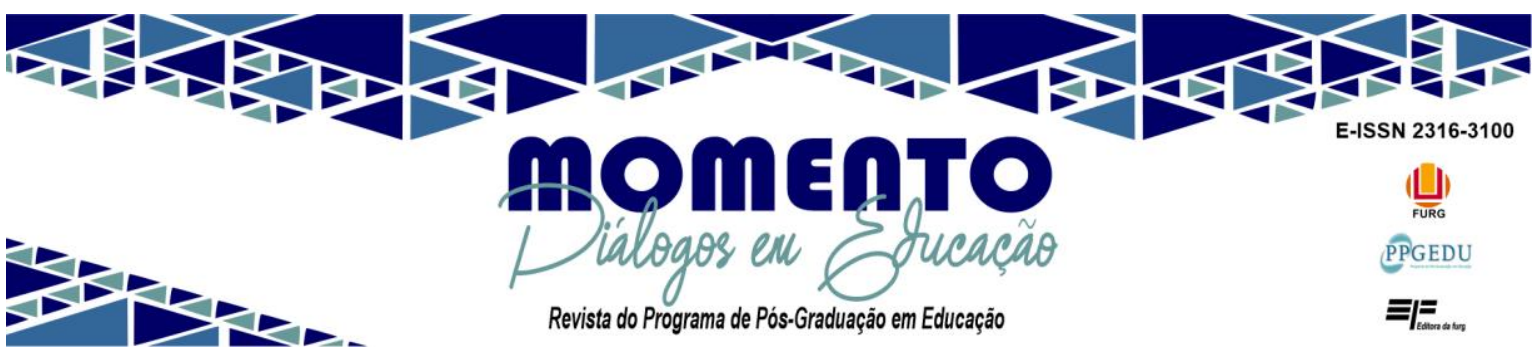

sendo representadas, geralmente, por um membro familiar. Dessa forma, na escola Amarela, a professora Maria usa o termo “quem cuida de mim”, entendendo que se há um responsável pelos cuidados com determinado aluno, esse é, então, a sua família e será a ela que a escola irá se dirigir quando necessário. Já a professora Iara, da escola Cinza, reforça que:

[..] Às vezes, é só uma avó, às vezes é só uma mãe, né. Às vezes, é um pai que cuida, que participa, que vem na escola, que há uma integração no ambiente familiar, que cuida da tarefa, que cuida do material, que se preocupa em vir na escola, sabe, ou fala com o professor, né, que vem em uma reunião. Essa criança tem um acompanhamento e uma vida escolar mais tranquila, né. Vou colocar assim. E quando não existe, a gente percebe, assim, quando tem algo de errado na escola, né. A gente percebe que o ambiente familiar não é propício. $\mathrm{O}$ que, às vezes, há brigas, separações, hoje em dia frequentes, mas depende do modo como as pessoas encaram essas separações. E também, assim, oh, não interessa a forma como essa família é constituída ou quem cuida, mas interessa se essa criança é cuidada, se é acompanhada, se ela é olhada, entendesse? Então, isso faz toda a diferença, com certeza.

Para as coordenadoras, a existência de uma pessoa que estabeleça o vínculo afetivo com o aluno é o suficiente para que o desempenho satisfatório das crianças aconteça.

Já para a professora da escola Amarela, o interesse familiar nas atividades escolares está cada vez mais distante dos alunos desde a educação infantil. Na escola Cinza, as famílias estão mais próximas e interessadas em participar do cotidiano da escola, bem como mais dispostas a contribuir para o bom desempenho escolar das crianças. Bronfenbrenner (2011) acredita no vínculo afetivo como mola propulsora para o desenvolvimento de uma criança. Para ele, isso basta.

Objetivando se desenvolver normalmente, uma criança precisa de envolvimento irracional de apoio de um ou mais adultos para o seu cuidado e para o conjunto de atividades articuladas a serem realizadas com essa criança. Em resumo, alguém tem que ser louco por essa criança. (BRONFENBRENNER, 2011, p. 279)

Nesse sentido, a criança que é amada tem, no vínculo afetivo, o atributo necessário ao seu desenvolvimento. Sendo assim, acredita-se nessa conexão como a base para que uma criança possa crescer no seu processo natural humano

Com relação à presença das famílias junto às aprendizagens dos alunos, a escola Amarela considera que a família precisa estar mais presente na escola, comparecer às 


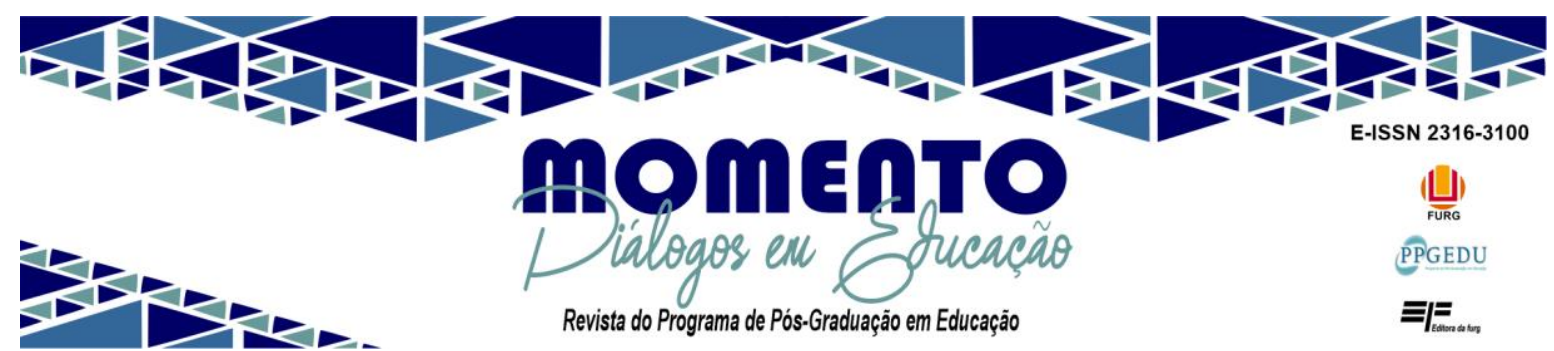

reuniões, buscar saber da proposta pedagógica. Já na escola $\mathrm{C}$, devido às dificuldades de aprendizagem das crianças na turma de $3^{\circ}$ ano, foi criado o que a coordenadora Jade chamou de "pequeno projeto", no qual quinzenalmente os pais são chamados para discutir formas de ajudar seus filhos nas atividades escolares. Ela ressalta que essa mobilização da escola tem sido positiva.

Esse tipo de ação interventiva frente às dificuldades dos alunos é relevante para o desenvolvimento dos discentes. Nesse sentido, a escola Cinza configurou-se como um agente social responsável com o ato de educar. Bronfenbrenner (2011) destaca a existência de uma resistência social em buscar compreender os pais:

Como uma sociedade que valoriza a independência e a autossuficiência, somos relutantes em assumir a responsabilidade de apoiar os pais, mas o preço dessa relutância pode ser observado na criminalidade, no fracasso escolar, nas crianças vítimas de negligência, nos casamentos e relacionamentos problemáticos e em outras tendências que enfraquecem os valores que nos são caros. Os estudiosos podem tentar corrigir ou ao menos amenizar esses problemas, partilhando os seus conhecimentos com as decisões políticas, como cidadãos e realizando pesquisas que orientem e avaliem novas políticas e práticas. (BRONFENBRENNER, 2019, p. 221).

Conforme o autor aborda no excerto acima, fazendo uma relação com o professor enquanto educador/pesquisador, observa-se que tal condição precisa ser analisada pelos contextos escolares. A formação superior que leva o sujeito a ser professor lhe dá base para investigar seu próprio ambiente escolar. Geralmente, o professor vê o seu papel docente desarticulado da pesquisa de seu próprio contexto de trabalho. Pensar em modos de articular a docência, em conjunto à pesquisa, pode ser, para escola, uma forma de sanar problemas que afligem as instituições. Através da coleta de dados, da criação de estratégias para o uso desses dados e da implementação de mecanismos, estes irão refletir no desempenho da escola e, consequentemente, nas crianças e nos jovens que se encontram dentro dela.

Por fim, as coordenadoras das escolas Amarela e Cinza demonstraram acreditar que a escola deve caminhar com a família e atrair os pais para um trabalho em conjunto. Ambas escolas demonstraram não estarem satisfeitas com o momento atual da relação em questão.

$\mathrm{Na}$ análise dos dados referente às entrevistas com as professoras das escolas Amarela, Branca e Cinza, a busca foi por compreender como as professoras articulam, no cotidiano 


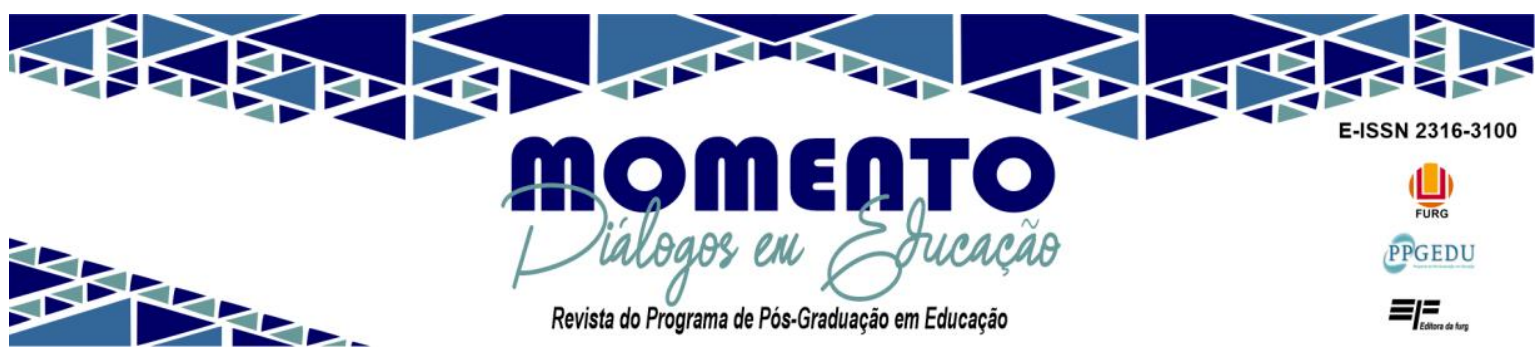

escolar, a presença das famílias e o que elas percebem nos alunos quando não há a participação dos pais nas atividades propostas por elas, como tema de casa, reuniões, entre outros eventos em que a presença da família se faz relevante.

As professoras das três escolas são unânimes em afirmar que a ausência familiar interfere muito na aprendizagem e no comportamento do aluno. A professora Joana, da escola Branca, relata que "o abandono da família é indiferente à classe social”, pois encontrou "crianças extremamente pobres com o material cuidado, enquanto outras crianças, que têm o poder aquisitivo alto, o descuido com o físico também é evidente". A professora Iara, da escola Cinza, diz: "Quando a família é muito ausente, o reflexo é muito nítido no aluno e isso interfere muito na aprendizagem e no comportamento do aluno". Para a professora Maria, da escola Amarela, "Em muitos casos, o emocional do aluno fica abalado e, consequentemente, há um bloqueio muito significativo na aprendizagem do aluno". A partir desses relatos, a pesquisa buscou observar como as professoras procedem na promoção de momentos em que aconteça a aproximação familiar nas atividades escolares dos alunos. Desse modo, a professora da escola Amarela relatou o seguinte:

[..] Sim, promovo atividades em que os pais participam da vida escolar dos seus filhos. Geralmente são tarefas que devem ser feitas em casa (tema) ou eventos maiores, como a feira de ciências que ocorreu neste ano em nossa escola, na qual eu solicitei, aos pais, que ajudassem seus filhos a pesquisar uma experiência, fazer experimentações em casa, para que os alunos apresentassem em nossa Feira. Realmente foi muito positivo, pois todos os pais se envolveram juntamente com seus filhos e realizaram com empenho o que foi proposto.

Já a professora Joana, da escola Branca, relatou ter desistido de fazer atividades extraclasse por entender que os pais não atendem a criança conforme ela gostaria:

[..] Já tive vários tempos, vários momentos da minha carreira, tenho trinta e quatro anos de magistério, que eu tentei muitas vezes fazer esse tipo de interação. Com o passar do tempo, vi que isso aí era perda de tempo muitas vezes. Por quê? Porque os pais, com a falta de tempo da vida deles, do cotidiano, da rotina, né. O que eles preferem? Fazer a atividade, resolver a atividade, fazer aquela atividade sozinho, entregar para o aluno e dizer que interagiu com ele. E a criança chega na escola totalmente perdida, né, porque foi orientado pelos familiares a dizer que fez com o pai, com a mãe, ou com o irmão, ou sei lá com quem, com a família reunida, né, quando, 


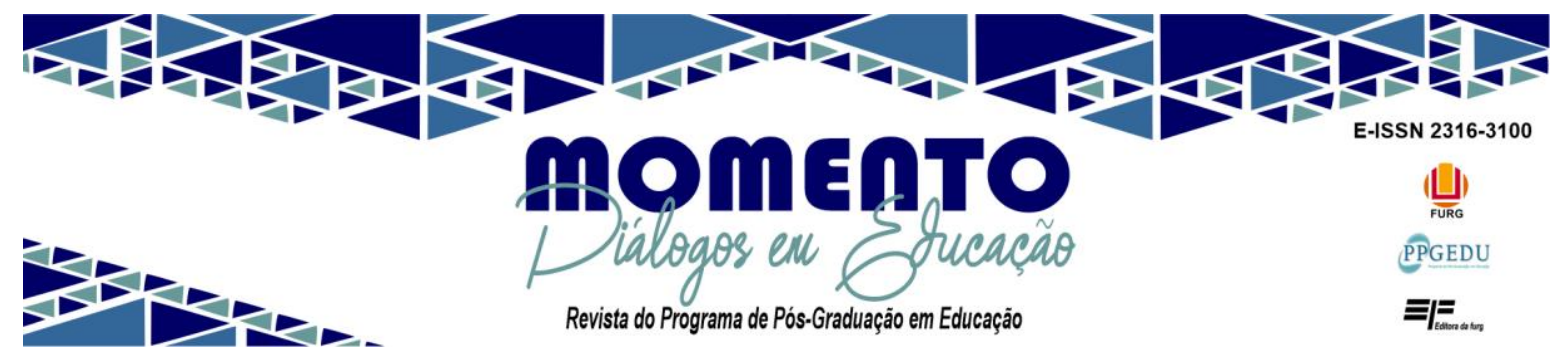

na verdade, era mentira, por falta de tempo ou por não querer interagir com a criança. - Ah, não me enche que agora eu não tenho tempo! Ou... As próprias crianças exteriorizam isso. Com o tempo, eu fui desistindo das atividades de interação com a família.

Para a professora Iara, de acordo com o que já foi posto por Jade, coordenadora pedagógica dessa escola, a ideia é envolver as famílias na tarefa de educar as crianças. Assim, ela diz:

[..] Sim, a escola tem propiciado atividades quinzenalmente para os pais responsáveis, a fim de melhorar o desempenho escolar dos alunos. As reuniões acontecem de $15 \mathrm{em} 15$ dias ao final de uma tarde, na qual vários assuntos são tratados: participação das famílias nos estudos, temas, inclusão.

Diante dos relatos das professoras, observa-se que cada uma tem uma fala sobre a ação das famílias nas aprendizagens escolares. Desse modo, observa-se a importância de os professores acreditarem em uma aproximação com as famílias. Bronfenbrenner (2011) aponta a família como coração social, dizendo:

\begin{abstract}
De todos os contextos que nos ajudam a sermos humanos, a família fornece as condições de desenvolvimento mais importantes: o amor e o cuidado que uma criança necessita para se desenvolver com sucesso. Uma criança que se transformará em um futuro adulto saudável é aquela que tem pessoas dedicadas, ativamente engajadas em sua vida - aquelas que amam, que passam tempo com ela e estão interessadas no que ela faz e quer fazer, no que realiza no dia a dia. Outros contextos, como a escola, a igreja, ou a creche são importantes para o desenvolvimento da criança, mas ninguém pode substituir esta unidade básica do nosso sistema social: a família é o mais humano, o mais poderoso e o sistema mais econômico conhecido para tornar e manter os seres humanos mais humanos. (BRONFEMBRENNER, 2011, p. 279)
\end{abstract}

Considerando as palavras do autor, entende-se o papel da família para o desenvolvimento de uma criança, no entanto, conforme as palavras trazidas pelas professoras e coordenadoras pedagógicas participantes das entrevistas, nem sempre os pais se dão por conta de sua importância frente ao desenvolvimento de suas crianças no que se refere às aprendizagens escolares ou sequer compreendem os reflexos dessa ausência no desenvolvimento desses indivíduos. Dessa forma, diante do diagnóstico trazido pelas professoras das escolas entrevistadas, existe a necessidade de se pensar na implementação de projetos dentro das instituições que busquem compreender como as famílias têm se visto 


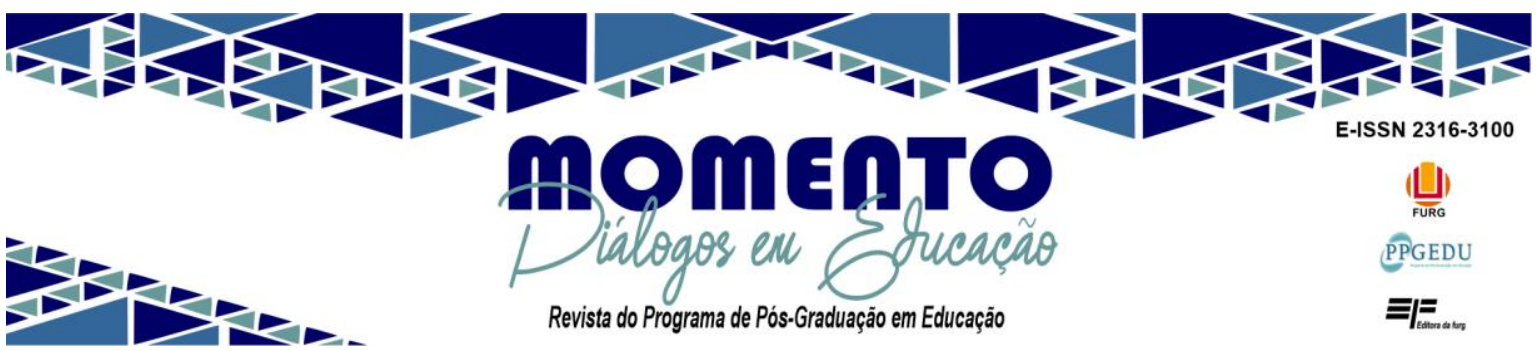

frente ao seu papel, a fim de que se trabalhe na sua conscientização enquanto promotoras do sucesso de suas crianças na vida.

No que se refere às entrevistas realizadas com as famílias, a pesquisa buscou, em um primeiro momento, entender o vínculo dos entrevistados com as crianças e, nesse sentido, todas as famílias manifestaram forte vínculo afetivo. Em um segundo momento, buscou-se compreender o que elas pensam sobre a sua participação nas atividades propostas pela escola, se dedicam seu tempo para trabalhar com seus filhos diante do que foi proposto pela escola e se consideram que os indivíduos que compõem a comunidade escolar exercem influências sobre suas crianças. Finalizando a entrevista, perguntou-se qual sugestão teriam para que fosse possível uma relação família-escola que colaborasse com as aprendizagens das crianças. Assim, entre os relatos, destacou-se o quanto consideram a escola como um espaço relevante para o desenvolvimento e a aprendizagem de suas crianças, embora tenham demonstrado nem sempre ter domínio de conhecimento acerca dos conteúdos trabalhados pela escola, entre outros aspectos, acerca do desenvolvimento infantil, em que o conhecimento familiar pode ser relevante ao desenvolvimento de uma criança.

Conforme se sabe, não há um curso específico formativo institucionalizado para que um sujeito se torne mãe/pai ou responsável. Esses papéis familiares se dão de forma transdirecional na vida. Desse modo, para muitas famílias, o apoio escolar é fundamental em certos casos de desconhecimento acerca da complexidade do desenvolvimento infantil, principalmente no período escolar, como o caso de uma criança com dislexia, trazido nesta pesquisa. Assim, embora a família deseje contribuir com o desenvolvimento da criança que se encontra sob seus cuidados, seus conhecimentos nem sempre são suficientes para dar conta das demandas que poderão vivenciar. Nesse sentido, Regina, mãe de W., relatou:

[..] O W é disléxico. No começo foi uma ignorância minha, por não saber da existência disso, né. E acabei, até acredito que no começo fui prejudicando ele, por não entender, né. Ele começava a chorar, pela minha discussão, de: - Vamos lá, vamos fazer, como é que tu não sabes? O que acabava prejudicando ele. Hoje, o que a gente tem de entendimento a gente faz, do possível e do impossível para ajudar ele, as dificuldades dele. E, realmente, quando a gente realmente teve entendimento do que ele tinha $\mathrm{e}$ do que ele não tinha foi que ele começou a deslanchar, que ele teve a compreensão do pai e da mãe, e a gente supriu as necessidades que ele precisava para ser ajudado. 


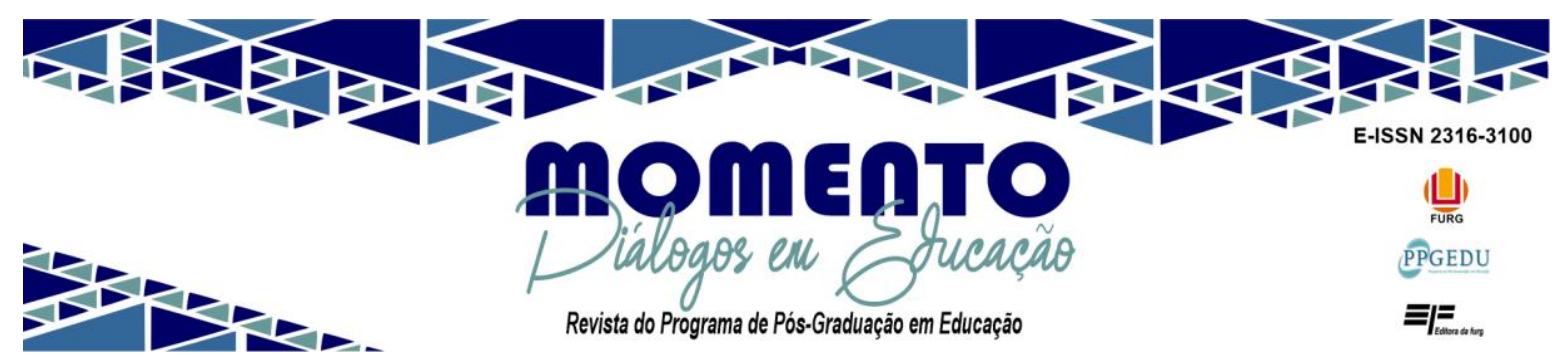

No caso do trecho da entrevista acima, Regina relatou somente ter descoberto as dificuldades de aprendizagem de seu filho no $3^{\circ}$ ano, quando ele passou a realizar provas como processo avaliativo. A dislexia fugiu à compreensão familiar, que necessitou do apoio da escola para atender às necessidades dessa criança que passou a receber atendimento com psicopedagoga particular. No entanto, no que se refere às crianças da rede pública de ensino, nem sempre isso é possível, devido a questões financeiras, havendo a necessidade de apoio do Estado a partir das políticas públicas. Bronfenbrenner (2011) refere-se ao macrossistema como aquele que permeia todas as esferas trazidas em sua teoria, até que atinja a criança. Dessa forma, os aspectos socioeconômico-culturais dos indivíduos, já adultos, interferem no desenvolvimento infantil daquele que se encontra sob sua tutela. No caso daquelas famílias que não possuem recursos financeiros, a dependência de políticas públicas torna-se evidentemente necessária, diante dos conhecimentos que irão demandar a fim de que possam ajudar seus filhos no seu desenvolvimento.

Não somente em questões mais severas relativas à aprendizagem as famílias necessitam de apoio da escola para ajudar seus filhos, mas também em situações corriqueiras o desconhecimento familiar interfere no desenvolvimento das crianças e pode ser nocivo a elas, mesmo sendo uma tarefa de casa. Assim, durante a entrevista, a mãe Yasmim falou sobre momentos que tenta ajudar o filho no tema escolar: "Tenho, tenho um pouco de dificuldade, eu acho que tenho". Já, em outro contexto, a mãe Janete coloca:

[..] Não. Eu e meu esposo acompanhamos os cadernos dele quando ele não consegue entender alguma coisa, porque ele escreve tudo sozinho, os temas ele faz tudo sozinho. Mas quando ele não consegue entender e a gente também não, a gente pede para ele perguntar para a professora, né, porque tem coisa que a gente não entende, e ele também não. A gente diz para ele: - Pergunta para a professora, que a professora vai te dizer. Uma atividade foi um desenho que a gente viu e não conseguimos entender o que que era. Aí, ele foi, perguntou para a professora. No outro dia, ele disse pra nós o que era.

Tanto no caso que se referiu à criança com dislexia quanto no caso das tarefas escolares que os pais não possuem conhecimento suficiente para atuarem como orientadores, observou-se que a escolarização dos pais interfere no desenvolvimento das crianças. No caso desses três relatos, as mães não possuem ensino fundamental completo, o que demonstrou que, embora estejam dispostas a auxiliar seus filhos, dependem de apoio de outras pessoas, 


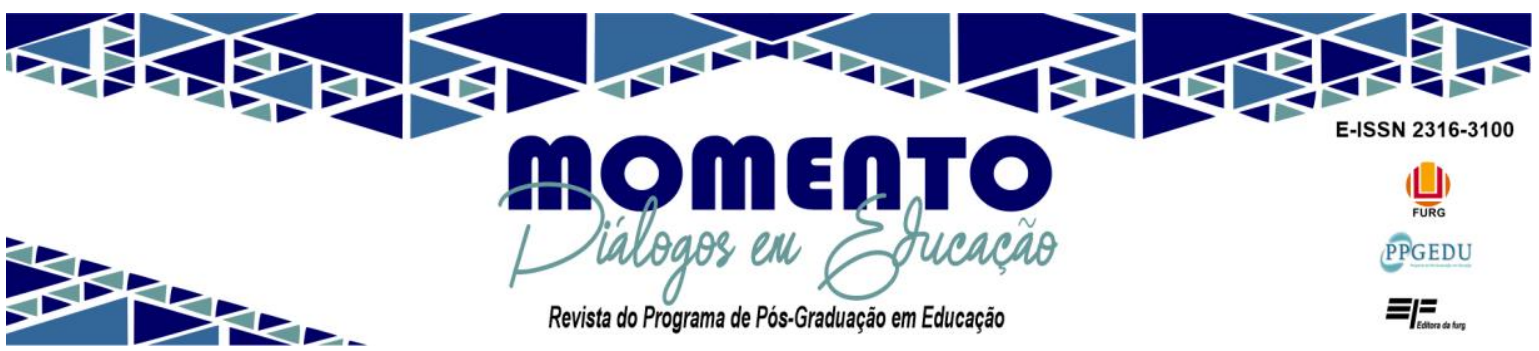

o que traz o entendimento de que a escola é um ambiente fundamental à vida familiar. Desse modo, Bronfenbrenner diz:

As crianças precisam de cuidado consistente e confiante de seus pais e outros adultos; mas, para prestar cuidados os pais precisam de apoio das entidades empregadoras, escolas e sociedade. Da mesma forma que estamos nos tornando mais conscientes de que temos a capacidade de destruir o ambiente natural, devemos tomar medidas energéticas para o preservar, temos que usar nosso crescente conhecimento sobre a ecologia do desenvolvimento humano para protegê-lo e fortalecê-lo das ameaças que involuntariamente criamos. (BRONFENBRENNER, 2011, p. 277).

$\mathrm{Na}$ perspectiva do autor, para que se torne efetiva a prática do cuidado com as crianças, os pais precisam de suporte, e uma forma de fomentar esse suporte seria a busca, da escola, para conhecer as famílias das crianças, compreendendo sua origem, seu sustento econômico, seus meios culturais, entre outros aspectos relevantes e específicos para cada contexto, olhando e respeitando as especificidades de cada sujeito que ocupa seus bancos.

Com relação às sugestões que as famílias trouxeram para o aprimoramento da relação família-escola, ouviu-se o seguinte da mãe Núbia, que cursou o ensino superior:

[...] Que os pais se permitissem. Não vissem a escola como uma barreira, e sim como uma aliada. Que fizessem com que seus filhos sentissem segurança e prazer de ir na escola. E não: - Vais na escola porque tu tens que ir; - Vais para escola porque tu tens que estudar, porque se tu não fores, eu vou preso, ou porque o conselho tutelar vai te levar de mim. Não é isso, tu tens que estimular teu filho. - Vai pra escola, porque lá é bom, porque tu vais aprender, porque tu vais ser alguém na vida. Porque lá tu vais ter amparo tanto quanto de casa. Se um dia acontece alguma coisa em casa, e tu não podes contar em casa, tu podes contar na escola. E a escola vice-versa com os pais: - Olha, vocês podem chegar aqui, vocês podem conversar, vocês têm a liberdade de chegar na escola. Assim como a liberdade da escola chega até a tua casa através do teu filho. É assim que eu penso.

Núbia demonstrou, em suas palavras, que os pais devem transmitir confiança aos filhos para que estes entendam a escola como um ambiente positivo e, assim, todos possam tirar proveito da instituição. Já a familiar Jurema considerou outras questões relevantes para serem pensadas diante do contexto escolar. Assim, ela diz:

Eu acho que a relação família e escola pode resolver em partes, sim, mas em outras partes, não. (...) eu acho que pode contribuir em relação aos alunos e à participação dos pais na escola, mas em termos de ensino, não 


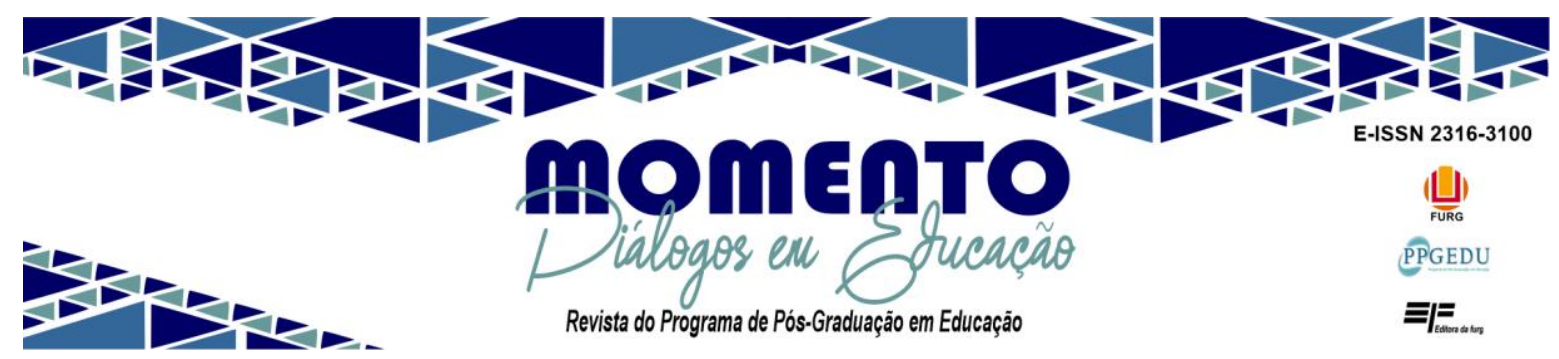

sei se teria influência, pois, como eu te disse, é uma estrutura, e aí o professor, ele viu que aquele aluno tem uma dificuldade ou tem progresso, ele não tem como trabalhar caso a caso. Não tem. A estrutura não permite, então, é o que a gente está vendo, retrocedendo os quatro para acompanhar os onze atrasados. Mas eu acho que seria importante essa relação. Não sei se para a estrutura de ensino faria alguma diferença, mas acho que chamaria mais a responsabilidade dos pais para participarem mais e verem os problemas. Oh! - Por que que meu filho está tendo algumas atitudes, ou não está querendo participar? E, aí, desenvolver na criança, eu acho. Mas na estrutura de ensino, a família não tem influência. Mas para trabalhar o aluno, o filho, seria bem interessante, para tu conheceres as dificuldades. Qual a dificuldade que teu filho tem? O que ele está apresentando? Como se comporta no colégio? A que ele não está se adaptando no colégio? O que ele não gosta? Se ele tem algum problema com algum coleguinha, por que tem? (JUREMA, FAMILIAR DE ALUNO, 2019).

Embora Núbia (2019) acredite que a escola corrobora, sob vários aspectos, com o desenvolvimento das crianças e que os pais devem confiar no trabalho da instituição, Jurema (2019) ressalta que nem todas as questões escolares estão sob o controle da escola de maneira que possam contribuir com o desenvolvimento dos alunos, pois acredita que certas questões fogem do poder institucional escolar, devido a estarem atreladas a questões da estrutura do sistema educativo, instituído e determinado pelo Estado.

Ainda, buscando compreender aspectos que as famílias enxergam como possibilidade para o aprimoramento da relação família-escola, observou-se, durante as entrevistas, uma certa dificuldade de estruturação de uma resposta para a problemática em questão. Assim, ouviu-se de Yasmim: "Sinceramente, no momento assim, não me vem nada na cabeça, acredito que deve ter, sim, sempre tem meios de ajuda, mas, no momento, não vem nada na cabeça". Janete, disse não ter nenhuma sugestão, assim como Regina (2019), que também não opinou a respeito do assunto. Já para Jurema, os pais poderiam contribuir com serviços braçais.

Diante do exposto, que buscou compreender entre os familiares como pode se dar o aperfeiçoamento da relação família-escola, percebeu-se que esse trabalho de pesquisa pode ter sido o primeiro movimento de questionamentos acerca dessa relação, já vivenciados, aspecto que se entende como uma ação necessária, a fim de que as famílias cheguem a uma tomada de consciência sobre os espaços e a função que ocupam na sociedade, através da possibilidade de reflexão acerca do tema e da sensibilização à relevância dessas vivências para o desenvolvimento das suas crianças. 


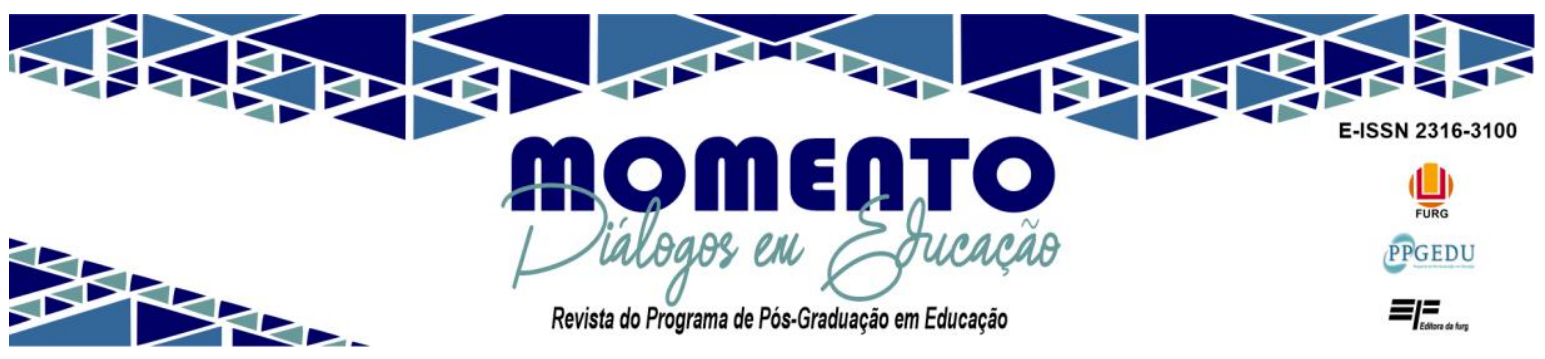

Considerações finais

Por tudo o que foi apresentado, pode-se compreender que a relação entre família e escola na comunidade do Povo Novo vem funcionando de uma maneira em que os sujeitos envolvidos acreditam estar empenhados para cumprir o seu papel na educação das crianças. Todavia, há algumas fragilidades nesse relacionamento, que dificultam uma atuação sistêmica em prol do processo de ensino e aprendizagem.

Acredita-se que a teoria bioecológica pode contribuir para o entendimento da relação entre esses microssistemas e para a busca por soluções coletivas, uma vez que aborda a complexidade que envolve as relações entre os indivíduos.

Nessa direção, pode-se, por exemplo, conceber que quem educa precisa estar amparado por conhecimentos conscientes, forjados em princípios morais e éticos, embora se observe que, na sociedade contemporânea, há uma vasta gama de empecilhos econômicos, culturais e sociais que complicam a busca por esses conhecimentos.

Entende-se também o papel da ciência, em especial a que lida com o social e o humano, bem como com as políticas públicas em um contexto macro. A ciência costuma ser produzida pelas universidades, cuja função é auxiliar seus estudantes para que, dali, enquanto profissionais graduados, mestres e doutores, construam opinião crítica e formulada acerca da realidade social e trabalhem em favor de propiciar o avanço científico, tecnológico, político e cultural de maneira comprometida com e para a sociedade.

Além disso, na lógica de que a família é o coração do sistema social e que os educadores das instituições escolares possuem formação científica, defende-se a ideia de que, embora entendendo quão árdua é a tarefa de educar, precisa-se buscar formas para que esses microssistemas se relacionem de forma profícua, a fim de que ambos se reconheçam dentro dos seus papéis sociais de maneira construtiva, permeados pelo afeto e em favor do desenvolvimento humano.

\section{Referências}

BRASIL. Lei de Diretrizes e bases da educação brasileira (LDB) de 1996. Brasília, DF: Presidência da República, $1996 . \quad$ Disponível em: http://www.planalto.gov.br/ccivil 03/leis/19394.htm. Acesso em: 16 nov. 2020.

BRASIL. Diretrizes Curriculares Nacionais Gerais da Educação Básica. DF: Ministério 


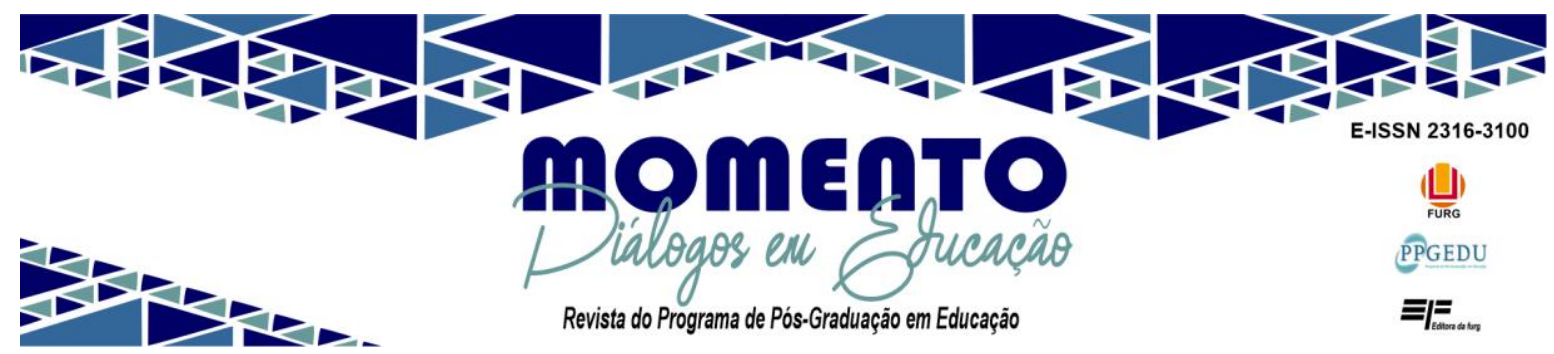

da Educação. Secretária de Educação Básica, 2013. Disponível em: http://portal.mec.gov.br/docman/julho-2013-pdf/13677-diretrizes-educacao-basica-2013pdf/file. Acesso em: 17 nov. 2020.

BRASIL. Estatuto da Criança e do Adolescente de 1990. Brasília, DF: Presidência da República, 1990. Disponível em: http://www.planalto.gov.br/ccivil_03/leis/18069.htm. Acesso em: 16 nov. 2020.

CASTRO, Jane Margareth; REGATTIERI, Marilza. Interação escola família para práticas escolares de 2010. DF: Unesco-Ministério da Educação. Disponível em: http://portal.mec.gov.br/index.php?option=com_docman\&view=download\&alias=4807escola-familia-final\&Itemid=30192. Acesso em 21 de nov. 2020.

BRONFENBRENNER, Urie. A ecologia do desenvolvimento humano: experimentos naturais e planejados. Urie Bronfenbrenner. Porto Alegre: Artes Médicas, 1996.

BRONFENBRENNER, Urie. Bioecologia do desenvolvimento humano: tornando os seres humanos mais humanos. Porto Alegre: Artmed, 2011.

CARVALHO, Maria Eulina Pessoa de. Relações entre família e escola e suas implicações de gênero. Cad. Pesquisa. online, n. 110, 2000. Disponível em: https://www.scielo.br/pdf/cp/n110/n110a06 Acesso em: 20 de nov. 2020.

LIBÂNEO, José Carlos. Organização e Gestão da Escola: teoria e Prática. Goiânia: Alternativa, 2001.

MARTINS, Edna; SZYMANSKI, Heloisa. A abordagem Ecológica de Urie Bronfenbrenner em estudos com Famílias. Estudos e pesquisa em psicologia. UERJ, Ano 4 N.1, $1^{\circ}$ Semestre 2004. Disponível em:

http://pepsic.bvsalud.org/scielo.php?script=sci_arttext\&pid=S1808-42812004000100006.

Acesso em: 10 de nov. 2020.

PIZZANI, Luciana. A arte da pesquisa bibliográfica na busca do conhecimento. Revista digital de biblioteconomia e ciência da informação. UNICAMP, vol.10, $\mathrm{n}^{\mathbf{0}} 1,2012$. Disponível em: https://periodicos.sbu.unicamp.br/ojs/index.php/rdbci/article/view/1896. Acesso em: 18 de nov. 2020.

SZYMANSKI, Heloisa. Entrevista reflexiva: um olhar psicológico para entrevista em pesquisa. Psicologia da Educação. Programa de Estudos Pós-Graduados em Educação: Psicologia da Educação, n. 10/11, fev. 2019. Disponível em: https://revistas.pucsp.br/psicoeduca/article/view/41414. Acesso em: 09 de nov. 2020.

Submetido em: 25-04-2021

Aceito em: 09-09-2021 